\title{
Vibrafone: uma fonte de coloridos sonoros
}

\author{
Fernando Chaib (Universidade de Aveiro, Aveiro, Portugal) \\ fernandochaib@gmail.com
}

Resumo: 0 artigo aborda questões práticas relativas à performance musical no vibrafone. Conceitos técnicos para a execução do repertório destinado a esse instrumento, geralmente transmitidos via tradição oral, são aqui ilustrados e formalizados afim de estabelecer um critério mínimo na bibliografia especializada em performance musical. Para isso são utilizados exemplos musicais extraídos de obras consagradas no cenário musical contemporâneo. Este trabalho poderá servir como ferramenta para o desenvolvimento pedagógico e artístico de percussionistas e compositores.

Palavras-Chave: vibrafone; performance musical; exploração tímbrica.

\section{Vibraphone: a source of sounding colors}

Abstract: This article poses practical questions about musical performance on the vibraphone. Technical concepts for the vibraphone's repertoire, traditionally transmitted orally, are illustrated and formalized into a minimal criterion that can be integrated into the specialized musical performance bibliography. To this end, musical excerpts from standard works in the contemporary music scene are utilized. This work aims to contribute to the existing body of knowledge by providing a pedagogical and artistic developmental tool for composers and musicians.

Keywords: vibraphone; musical performance; timbrical exploration.

\section{Introdução}

As constantes buscas por compositores e intérpretes da música do século XX por uma originalidade estética que rompesse com dogmatismos e regras composicionais preestabelecidas acarretaram produções musicais onde os convencionalismos eram pouco a pouco descartados. Isso incluiu o modo tradicional de como o som, característico de um repertório específico, era extraído de um instrumento. Alguns compositores resolveram explorar 0 timbre dos instrumentos de formas inusitadas, fora dos padrões tradicionalistas de extração do som existentes até então. Essas pesquisas sobre o timbre na música ocidental do século XX pontificaram estudos sobre certos instrumentos que resultaram no desenvolvimento de diferentes meios de exploração do som.

Os instrumentos de percussão, estando em voga nas produções de compositores como Ives, Cowell, Cage e Milhaud foram determinantes para o encontro dessa "não convencionalidade" tão quista pelos contemporâneos da primeira metade do século XX. Dentre esses instrumentos o vibrafone destacou-se por se apresentar extremamente versátil no que diz respeito à capacidade de se conseguir uma gama considerável de sonoridades particulares ao mesmo, tornando-se um verdadeiro laboratório tímbrico para compositores e intérpretes no decorrer do século precedente:
Dentre os instrumentos de percussão há várias razões para que 0 vibrafone tenha se destacado. Uma das razões está na capacidade de produzir uma grande diversidade sons, inventivos e próprios ao instrumento. [...] Um dos seus traços marcantes é possuir um controle de duração e articulação do som impressionantes. A possibilidade do uso do pedal juntamente com a possibilidade de ir abafando as notas permite todo tipo de legatos, meio legatos e staccatos. 0 pedal permite uma grande sustentação do som além de sua fácil interrupção. Além disto, o instrumento possui uma ampla variação de dinâmica. [...] Ou seja, esse instrumento se destaca em meio ao conjunto dos instrumentos de percussão, já que são muito poucos os instrumentos dessa família que possibilitam o controle simultâneo de todos esses aspectos do fazer musical. ZAMPRONHA (2007).

0 presente artigo tem por objetivo a apresentação de algumas técnicas capazes de extrair diferentes sonoridades no vibrafone: a sua exploração tímbrica. Explanaremos algumas problemáticas de execução através de exemplos musicais encontrados no repertório padrão do instrumento e procuraremos ilustrar de uma forma clara e concisa as soluções técnicas sugeridas para a sua performance. Um segundo objetivo desse trabalho será o de formalizar, na literatura especializada em performance musical, conceitos de execução no vibrafone geralmente transmitidos via tradição oral nos conservatórios musicais, escolas técnicas e de ensino superior. Uma vez formalizadas, essas informações poderão auxiliar pedagogicamente o desenvolvimento performativo do instrumentista em fase de aprendizagem. 


\section{Conceito de timbre}

É importante salientar que, tratando-se de um artigo que discutirá a performance musical no vibrafone, os assuntos aqui discutidos terão como cerne o fenômeno acústico resultante dos efeitos sonoros extraídos do instrumento, não envolvendo quaisquer outras questões. Ao se discutir pontos relativos à exploração tímbrica fazse necessário o esclarecimento do conceito de timbre, uma vez que definições equivocadas podem comprometer a compreensão dos assuntos aqui apontados. Pierre Schaeffer o define procurando não deixar margem para dúvidas que o possam desvincular do seu real conceito enquanto fenômeno sonoro:

0 timbre de um objeto não é outra coisa se não sua forma e sua matéria sonora, sua completa descrição, dentro dos limites dos sons que pode produzir um certo instrumento, tendo em conta todas as variações de execução que ele permite'. SCHAEFFER (1966, p.232).

Podemos concluir por essa afirmação que o timbre possuirá, intrinsecamente, uma variedade sonora. Poderá se apresentar através de sonoridades distintas mas com características semelhantes entre si, permitindo identificar a sua origem partindo de um mesmo instrumento. A exploração tímbrica em um determinado instrumento não alterará o seu timbre, apenas nos permitirá identificar as variantes sonoras que ele pode oferecer mediante os meios de execução possíveis.

Partindo do princípio que essa designação não era (e não é) algo particular à música, foi possível, entre outros exemplos e explicações encontrados, fazer uma relação entre o som e as cores. Podemos citar Varèse, Stockhausen, Antunes e López López, dentre tantos outros compositores que, ao procurarem exemplificar um determinado som característico, chamar-lhe-ão de cor do som ou colorido sonoro. É interessante percebermos que os artistas plásticos também falam em timbre, cromatismo e tonalidade quando se referem a um quadro com um tipo característico de coloração. A união de várias cores produzirá uma outra resultante dessa mescla. Da mesma forma, a união de vários harmônicos e/ou inarmônicos relacionados a um som em específico nos permitirá identificar as diferenças vibratórias, de frequência ou intensidade que caracterizarão a formação do timbre do som e suas variantes.

2.1. Aplicação do conceito de timbre no vibrafone Quando tocamos o vibrafone com baquetas, arcos de instrumentos de cordas ou dedos, extraímos do instrumento certos tipos de sonoridades que possuem algumas características semelhantes e outras distintas. As características sonoras distintas ocorrerão pelo modo de ataque e material do artefato com o qual o instrumento é manipulado, acarretando incidências diversas de harmônicos, o que valorizará para mais ou para menos a nota fundamental. As características sonoras semelhantes existirão por se tratar do mesmo instrumento. Ou seja, mesmo utilizando baquetas, arcos ou dedos, conseguimos identificar que o instrumento executado é um vibrafone, pois o seu timbre permanece o mesmo. 0 que muda é a sonoridade do timbre, o seu colorido sonoro. Observando o repertório destinado a este instrumento, percebemos que existe uma grande quantidade de obras que exigem a manipulação de diferentes tipos de ferramentas para sua execução, somada aos mecanismos e características originais como o pedal, o motor e principalmente a possibilidade de uma ampla variação de dinâmica, como afirma FRIEDMAN (1987, p.2) "[...] 0 contraste das dinâmicas é o que faz o vibrafone respirar".

Nos concentraremos em exemplificar algumas variações sonoras relativas ao timbre do vibrafone que se distanciam do som original ${ }^{2}$ (no entanto, bastante recorrentes em obras de grande relevância para o repertório do vibrafone). Discorreremos também sobre alguns pontos técnicos essenciais que nos ajudarão a compreender melhor de que modo as ressonâncias são extraídas e como elas podem variar, dependendo do controle dos mecanismos existentes no instrumento em sua origem ou artefatos confeccionados para sua execução (baquetas e outros objetos). Portanto, chamamos a atenção para uma questão particular ao intérprete que será substancialmente relevante para que as questões aqui discutidas tenham de fato um resultado positivo na prática: a percepção auditiva das ressonâncias extraídas do instrumento. É comum aos intérpretes dos instrumentos de lâminas uma preocupação extrema com a harmonia (ou melodia) de uma obra executada, esquecendo-se da qualidade tímbrica que melhor se enquadrará num determinado contexto musical. 0 intérprete, em geral, sente-se satisfeito se 0 ataque de um acorde com as quatro baquetas ressoar as notas desejadas, mas descuida-se ao realizar esse gesto explorando diferentes regiões das lâminas obtendo um som desigual, heterogêneo, dissemelhante do que se espera sonoramente de uma determinada passagem. Por outro lado, o fato de a maioria desses intérpretes serem percussionistas contribui para um conceito equivocado de extração do som dos instrumentos de lâminas. Não é raro observarmos instrumentistas que se utilizam de um mesmo gesto de articulação para tocar um vibrafone e, por exemplo, um tom - tom. É preciso separar os conceitos técnicos que melhor se aplicarão para cada instrumento pois, inversamente, um gesto para realizar um ataque sobre as lâminas do vibrafone também não será o mais adequado para a execução de um toque articulado em um tom - tom. Existem obras que requerem diferentes resultados sonoros do instrumento, mas elas são bastante específicas a esse respeito. Caso contrário, o intérprete deverá ter o cuidado de explorar homogeneamente 0 som do instrumento, adquirindo um equilibrio sonoro, adequado ao que a música se propõe. Mesmo em casos onde a exploração tímbrica se dá com outros artefatos, 0 intérprete deverá primar pela coerência dos sons extraídos relativos à passagem musical que se deseja demonstrar.

0 Concerto pour Vibraphone et Orchestre d̀ Cordes (1999) de Sejourné exemplifica bem algumas questões de variações sonoras, pois se utiliza de várias passagens onde o som do instrumento se descaracteriza do seu 
contexto original. A abordagem sobre os artifícios utilizados pelo compositor poderá também clarear a forma de interpretar e executar outras obras que exigem semelhante desenvoltura técnica. Utilizaremos também outras composições para exemplificar diferentes questões, a exemplo de 6 Unaccompanied Solos for Vibe (1966) de Burton, Links (1975) de Smith, Mirror From Another - A Collection of Solo Pieces for Vibraphone (1973) de Friedman, Rain Tree (1981) de Takemitsu, Cálculo Secreto (1994) de López López e Modelagem X-a (1997) de Zampronha.

\section{Meios de exploração tímbrica - Baquetas}

Um dos fatores determinantes para a exploração de diferentes sons no instrumento é o objeto manipulado pelo instrumentista. 0 vibrafone não foi concebido originalmente para ser executado com as mãos (ainda que hajam exceções para esse artifício em algumas obras, nas quais os compositores são bem explícitos com relação a esse uso). Na maioria dos casos, a sua execução se dá de forma indireta pelo intérprete. Isso significa que entre o instrumento e o instrumentista existe um objeto que interage, que cria um "elo" entre os dois.

0 principal artefato utilizado pelo intérprete é denominado, em língua portuguesa, baqueta (com o qual o vibrafone foi concebido originalmente para ser executado). Para os instrumentos de percussão compostos por lâminas denomina-se baqueta de teclados ${ }^{3}$ ou baqueta de lâminas ${ }^{4}$ (conhecida na literatura internacional especializada pela denominação mallet5). Uma observação acerca das baquetas de lâminas será importante para entendermos algumas questões que se seguirão no decorrer desse trabalho, pois tratase de um dos pontos principais de preocupação de compositores e intérpretes na composição e execução de obras destinadas ao vibrafone: "Certamente o tipo de baqueta pode modificar não só a sonoridade, mas a forma do ataque do som, o que permite modificar substancialmente o carácter de um segmento musical", ZAMPRONHA (2007). Essas baquetas são formadas por um "cabo" cilíndrico de madeira ou ratan ${ }^{6} \mathrm{com}$ medida variável entre $01 \mathrm{~cm}$ e $03 \mathrm{~cm}$ de diâmetro e comprimento entre os $15 \mathrm{~cm}$ e $20 \mathrm{~cm}$. Em uma das extremidades está afixada uma ponta (geralmente uma esfera, por vezes ligeiramente elíptica) à qual damos 0 nome de "cabeça" da baqueta, que chega a medir 1,6" de diâmetro. Essa ponta pode ser feita de materiais diversos (silicone, acrílico, plástico, borracha, madeira ou metal) mas para o vibrafone é confeccionada, em geral, com borracha e posteriormente revestida (cosida) com algum tipo de linha (lã, linho, seda, corda). Alguns modelos de baquetas extremamente duros podem substituir as borrachas por outro tipo de material (acrílico, silicone, plástico, madeira). No entanto, a escolha do tipo de borracha (dureza) e tipo de linha (dureza) são extremamente importantes para o som que se quer extrair do instrumento: a) Maiores níveis de dureza - maior incidência de harmônicos e som mais "brilhante" em toda a extensão do vibrafone. Maiores níveis de dinâmica e articulação mais clara. Exemplo: Cabeça confeccionada com material duro (acrílico, plástico, madeira, metal) sem revestimento ou revestida com material de grande dureza (linho ou lã dura);

b) Menores níveis de dureza - maior incidência da nota fundamental na região grave (som mais "encorpado"). Pouca resposta sonora na região aguda do vibrafone. Menores níveis de dinâmica e pouca articulação. Exemplo: Cabeça com material mole (borracha ou plástico de pouca dureza) revestida com material de pouca dureza (lã, feltro).

A maleabilidade do revestimento da cabeça da baqueta também será importante. Se a linha for bastante apertada contra a esfera, resultará em um som mais característico do material com o qual a cabeça foi feita. Por outro lado, estando a linha envolvendo a cabeça com uma certa folga, o contato entre os dois materiais não será tão imediato resultando primeiramente num som característico da linha. 0 vibrafonista poderá, entretanto, combinar diferentes níveis de dureza entre a cabeça da baqueta e o material que a reveste, constituindo diferentes tipos de baquetas, proporcionando uma vasta exploração sonora. Devemos observar que devido ao seu tipo de costura a maioria das baquetas possuem, na extremidade de suas cabeças, uma concentração maior do material que a reveste, perdendo certo contato com esfera, proporcionando um timbre mais característico do material utilizado para envolvê-la.

Existem ainda as chamadas baqueta de duplo ataque?. Essas baquetas possuem uma característica peculiar em sua fabricação. Geralmente a sua esfera é confeccionada com um material duro (acrílico, silicone, plástico, madeira ou borracha dura) contendo uma parte de material de menor dureza (borracha mole ou espuma) circundando o seu eixo, além de possuir uma linha de pouca dureza (geralmente lã) revestindo a esfera com bastante maleabilidade. Assim, para a extração de dinâmicas em pianíssimo será ouvido o som característico do material menos duro ao passo que para dinâmicas fortes ouviremos o som do material com maior nível de dureza. Devemos deixar claro que a característica sonora extraída por uma baqueta de duplo ataque variará de acordo com a dinâmica. Com esse tipo de baqueta o som resultante extraído em dinâmica pianíssimo será completamente diferente de som extraído em dinâmica forte. Não podemos afirmar que todas essas baquetas são fabricadas com os mesmos materiais. Diremos então que, diferentemente das baquetas que possuem em sua cabeça um material para a fabricação da esfera e um para o seu revestimento, uma baqueta de duplo ataque terá, em sua maioria, três materiais que compõem a sua cabeça (o primeiro que origina a esfera, o segundo que a circunda e o terceiro que a reveste), permitindo uma variação sonora maior relacionada ao timbre do instrumento, sempre condicionada à dinâmica executada. 
Encontramos também no repertório para o vibrafone um tipo de baqueta que possui uma particularidade em sua fabricação: a sua esfera é constituída por dois tipos de material que possuem durezas diferentes (duro e macio). Não há qualquer material que circunda a esfera (como é o caso da baqueta de duplo ataque). A parte dura compreende a região do centro da esfera para baixo (em direção ao cabo) enquanto a parte macia compreende a região do centro da esfera para cima (ponta da baqueta). 0 principal motivo que causará a diferença do som extraído será, de fato, por conta do material com o qual é fabricada a cabeça da baqueta. Na obra Cálculo Secreto, López López, exige esse tipo de baqueta que não está padronizada no mercado, sendo recentemente implementada em uma rota limitada de comercialização (apenas por encomenda). Por esse motivo ela não tem uma designação oficial ou reconhecida pela literatura internacional que possa identificá-la. Para que possamos reconhecê-la e diferenciá-la dos outros tipos de baquetas, a denominaremos como baqueta de dureza oposta, já que a sua cabeça possui dois tipos de dureza distintos podendo ser executados em quaisquer níveis de dinâmica, sem prejudicar o seu resultado sonoro característico.

Nos livros e métodos existentes sobre os instrumentos de percussão de lâminas, a indicação da manipulação das baquetas está padronizada de forma numérica, sendo 1 e 2 as baquetas indicadas para a mão esquerda e 3 e 4 para a mão direita (da esquerda para a direita do corpo humano), como afirma BURTON (1996, p.3): "Em caso de possiveis dúvidas, eu anotei a manulação ${ }^{8}$ utilizada usualmente ( $E$ para esquerda e $D$ para direita) $)^{9}$. Em algumas ocasiões, anotei a manulação para a função de quatro baquetas como: 1-2 (mão E) e 3-4 (mão D)". 0 repertório para o vibrafone estabeleceu como material primordial para a sua execução as baquetas de ponta de borracha revestidas com linha ou lã. Isso, no entanto, não limitou a busca por novas sonoridades extraídas do instrumento com outros tipos de artefatos, como poderemos observar no decorrer do artigo.

\subsection{Ressonância}

0 vibrafone é o instrumento mais ressonante dentro da família dos instrumentos de percussão de lâminas. Isso explica-se pelo fato de as lâminas serem de metal, possuindo uma capacidade de vibração mais duradoura do que a madeira (no caso da marimba e do xilofone). Será também mais ressonante que 0 metalofone ${ }^{10}$, visto que esse não possui tubos ressonadores que ajudem na propagação do som e por ter suas lâminas fabricadas com um tipo de metal que possui menores níveis de vibração do que o alumínio em liga especial ${ }^{11}$ utilizado para a fabricação das lâminas do vibrafone. Além do mecanismo do pedal, que permite ao intérprete controlar temporalmente a vibração das lâminas, existe um outro fator determinante para que a ressonância do vibrafone possua maior ou menor incidência sonora. Trata-se da possibilidade da manutenção dos tubos ressonadores fechados ou abertos pelas placas circulares que se encontram acopladas em cada um deles.

Contrariando a ideia geral que se tem sobre a relação entre os tubos e a ressonância do instrumento, chamamos a atenção para a seguinte questão: estando os tubos abertos, a ressonância do vibrafone será a mais intensa possivel e terá uma duração de reverberação das lâminas razoavelmente curta, o que significa que a nota deixa de ser ouvida num curto espaço de tempo. Se mantivermos os tubos totalmente fechados, o som perderá intensidade em sua ressonância mas será, pelo menos, três ou quatro vezes mais longa a duração da reverberação das lâminas, mantendo as notas executadas audiveis por mais tempo. Existe a possibilidade de encontrar-se um "meio-termo" entre a ressonância e a reverberação das lâminas, deixando os tubos parcialmente abertos para valorizar-se os dois aspectos. Alguns vibrafonistas costumam dispor as placas, que se encontram acopladas nos tubos, num ângulo $x \mathrm{em}$ relação ao eixo cilíndrico procurando obter um melhor resultado sonoro para alguma execução em específico. 0 movimento das placas através do motor também alterará a duração e a ressonância do som. A velocidade do motor poderá ser controlada pelo intérprete, mediante os mecanismos possíveis de manipulação durante a execução de uma obra. 0 motor possui uma grande variedade de velocidade, permitindo os mais diversos niveis de tremoli que as placas circulares são capazes de produzir nos tubos, alterando também a durabilidade de reverberação das lâminas. Em certos casos o instrumentista deverá desenvolver mecanismos alternativos de controle da velocidade motriz. Almeida, ao executar o estudo Etude XIV ${ }^{12}$ concebeu a ideia de um "pedal" para regular a velocidade do motor, já que suas mãos encontravam-se ocupadas durante todo o trecho em que ele optou por variar os níveis de tremolo do instrumento:

0 motor do vibrafone que utilizei possuía um dispositivo para ligá-lo e desligá-lo e outro para controlar a sua aceleração e velocidade. [...] Pensei num dispositivo que tornasse possivel controlar a velocidade do motor com o pé esquerdo, e que fosse relativamente fácil de usar. 0 pedal possibilitou que eu mantivesse o motor girando à mesma velocidade da colcheia, em relação as notas do estudo. A medida que a música acelerava o andamento, o pedal era acionado e o motor aumentava a velocidade dos giros das placas circulares mantendo a relação de pulsação. [...] 0 pedal se mostrou útil para ligar o motor de forma mais cômoda em trechos que o intérprete é solicitado a ativar rapidamente o motor durante a troca de baquetas ou mesmo durante a execução de encadeamentos de acordes. ALMEIDA (2007).

Podemos observar nas tabelas a seguir, a relação temporal ${ }^{13}$ entre as notas Lá2 e Lá3 tocadas com os discos dos tubos ressonadores em diferentes posições (motor desligado, Ex.1) e em três níveis de velocidade (motor ligado, Ex.2): 


\begin{tabular}{|l|c|c|c|}
\hline & Tubo Aberto & Tubo Fechado & Tubo Semiaberto \\
\hline Lá 2 & 11 s48dc & $40 \mathrm{~s}$ & $25 \mathrm{~s} 62 \mathrm{dc}$ \\
\hline Lá 3 & $16 \mathrm{~s} 28 \mathrm{dc}$ & $44 \mathrm{~s} 13 \mathrm{dc}$ & $31 \mathrm{~s} 79 \mathrm{dc}$ \\
\hline
\end{tabular}

Ex.1 - Relação temporal entre notas e tubos ressonadores com o motor do vibrafone desligado, onde: $\mathrm{s}$ (segundos) e dc (décimo de segundos) significam o tempo de decaimento da nota a partir do seu ataque até a total ausência de som.

\begin{tabular}{|l|c|c|c|}
\hline & Velocidade lenta & Velocidade média & Velocidade rápida \\
\hline Lá 2 & $16 s 48 d c$ & $15 s 62 d c$ & $18 s$ \\
\hline Lá 3 & $25 s$ & $24 s$ & $22 s 56 d c$ \\
\hline
\end{tabular}

Ex.2 - Relação temporal entre notas e tubos ressonadores com o motor do vibrafone ligado, onde: s (segundos) e dc (décimo de segundos) significam o tempo de decaimento da nota a partir do seu ataque até a total ausência de som.

No Ex.2 as diferenças do tempo de duração de reverberação são menores em relação ao Ex.1. As notas Lá 2 e Lá 3 apresentam praticamente a mesma relação de durabilidade de reverberação com o motor em velocidade lenta e média. Curiosamente, estando o motor em alta velocidade, apresentam uma relação de tempo oposta. $A$ nota Lá 3 parece seguir uma coerência de menor duração quanto mais rápida for a velocidade do motor. Já a nota Lá 2 não corresponde a essa observação.

Para avaliarmos as medidas que se encontram nas duas tabelas deve ser levado em conta todo o espaço e material utilizado para realizar esse estudo. A acústica da sala em que se encontra o instrumento (nesse caso com pouca reverberação), as baquetas utilizadas, a intensidade com qual foi feito o ataque e o próprio instrumento tornam essas medidas muito particulares à essa observação. A relação entre as medidas poderá ser mantida apenas se as mesmas características de espaço, material utilizado e forma de ataque forem conservadas para todas as observações efetuadas. Salientemos que nessa observação, ao ressoar a nota Lá 2 com o tubo aberto, ouviremos a nota fundamental somente durante os sete primeiros segundos ficando logo após em evidência o harmônico n. 4 (nota relativa à fundamental duas oitavas acima). Isso aplica-se a toda a região grave do instrumento.

As lâminas ressoam por mais tempo com os tubos fechados porque a área de escape do som se torna limitada. Dessa maneira as ondas sonoras permanecem entre a lâmina percutida e a placa circular, num constante vaivém. Já com os tubos abertos, o som possui uma área de escape maior, o que resulta em uma vibração da lâmina sem interferências. A intensidade sonora será maior com o tubo aberto porque ele também passará a vibrar, aumentando a quantidade de harmônicos do som.
Utilizamos a região central das lâminas para realizar os ataques, ajudando na percepção das ressonâncias que o vibrafone é capaz de produzir a partir de uma nota fundamental. As lâminas possuem a característica de modificarem ligeiramente o som conforme as regiões percutidas. As áreas que compreendem o centro das mesmas (exatamente onde os tubos estão dispostos) e suas extremidades (pontas) terão a fundamental em total evidência, ao passo que à medida que formos aproximando os ataques dos pontos nodais, os harmônicos característicos da nota em questão começarão a ganhar evidência no som extraído, dividindo as atenções com a nota fundamental. Salientemos que para extrairmos uma sonoridade das extremidades das lâminas semelhante ao centro, é necessário realizarmos um ataque em seu limite, procurando um distanciamento de sua região nodal.

\subsection{Pedal:}

Para explorarmos o timbre do vibrafone com a intenção de obter diferentes resultados sonoros além de construir fraseados, motivos melódicos, rítmicos e encadeamentos harmônicos, faz-se necessário um controle bastante preciso do pedal. Buscando ajudar o intérprete nessa questão, os compositores procuraram estabelecer símbolos para indicarem o uso desse recurso em suas obras. Alguns símbolos e nomenclaturas são explicitados, nas partituras escritas para o vibrafone, apontando como devem ser aplicados os recursos no instrumento exigidos pelo compositor. É importante conhecermos primeiramente as denominações atribuídas às possibilidades de pedais existentes nas obras para vibrafone, se quisermos interpretar da maneira mais correta as peças estudadas:

a) Pedal aberto - Indica um apoio sobre o pedal com o intuito de desencostar totalmente a barra de abafamento das lâminas; 
b) Pedal fechado - Indica que não há qualquer apoio sobre o pedal, permanecendo a barra de abafamento totalmente encostada às lâminas;

c) Meio pedal - Indica uma leve pressão sobre o pedal, criando um meio-termo de atrito entre a barra de abafamento e as lâminas;

d) Pedal gradual - Indica que a barra de abafamento deverá encostar ou desencostar das lâminas gradualmente, abafando-as ou deixando-as ressoar pouco a pouco. 0 pedal gradual poderá ser executado em andamentos rápidos ou lentos.

$\mathrm{Na}$ literatura internacional destinada ao vibrafone temos diferentes tipos de escrita simbólica destinados a exemplificar o mesmo processo, como podemos conferir nos exemplos a seguir (cujos tipos são indicados por algarismos romanos), que demonstram os símbolos utilizados para sinalizar a utilização do pedal aberto:

Concerto Pour Vibraphone et Orchestre à Cordes, de Sejourné:

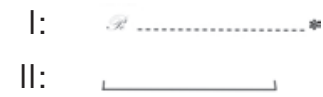

Links 2, de Smith:

III:

Mirror From Another - A Collection of Solo Pieces for Vibraphone, de Friedman:

IV:

6 Unaccompanied Solos for Vibe, de Burton:

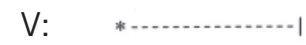

Rain Tree, de Takemitsu:

VI:

Em todos esses exemplos a linha contínua ou pontilhada na posição horizontal significa a manutenção do pedal aberto. A linha vertical (ou o asterisco) no final da linha horizontal significa o fechar do pedal (se está no início da linha, significa que o pedal eslava fechado antes de ser aberto). Note-se que, mesmo não seguindo um padrão de escrita simbólica, os compositores limitam os caracteres utilizados e ordenam-nos de maneiras diferentes, chegando a um símbolo característico (mas não exclusivo) para indicarem o uso do pedal. Sejourné (ver indicação I acima) chega a utilizar dois tipos de escrita simbólica na mesma obra para indicar o mesmo processo. Por sua vez, Takemitsu (ver indicação VI acima) pede apenas uma breve interrupção do pedal aberto seguido de uma nova abertura, visto que sua peça tem como uma de suas principais características a eminente presença de grandes ressonâncias extraídas do vibrafone. Outros tipos de escrita simbólica para o pedal indicam outras faculdades exequíveis desse mecanismo, como a indicação de meio-pedal e pedal gradual:

Ajax Men of Science (6 Unaccompanied Solos for Vibe), de Burton:

VII:

Rain Tree, de Takemitsu:

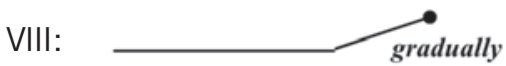

Links 2, de Smith:

XIX:

Smith não especifica realmente se sua indicação (ver indicação XIX logo acima) é de fato um meio pedal. Podemos interpretar dessa maneira (como podemos também atribuir um pedal gradual a essa simbologia) pois existe um símbolo diferente para o pedal aberto utilizado na mesma obra pelo compositor (Ex:3).

Diferentemente, Takemitsu especifica inclusive com a expressão gradually, a indicação do pedal gradual (ver indicação VIII acima). Observando que essa indicação vem posteriormente à indicação do pedal aberto podemos concluir que se trata de um pedal gradual em direção ao pedal fechado. Conforme os exemplos de escrita do pedal aberto, as indicações sobre outros tipos de pedal também não são uma prática padronizada. Vejamos a sinalização de staccato, meio-pedal e $1 / 4$ de pedal exigido por López López em determinado trecho de sua obra Cálculo Secreto ${ }^{14}$ (Ex: 4).

Sugerimos que o uso do pedal (de maneira geral) seja feito da forma mais suave e delicada possível. 0 pé sobre o pedal deverá agir de uma forma bastante sutil. 0 peso aplicado deverá ser o suficiente para que se consiga 0 efeito esperado de abafamento. Não se deve aplicar uma força-peso além do necessário, com o risco de danificar o mecanismo do instrumento ou criar certos ruídos indesejáveis à performance. Não há necessidade de 0 pedal encostar-se ao chão, quando esse for acionado. Os dois pés devem ser utilizados alternadamente, conforme a região do instrumento executada, contribuindo para um posicionamento corporal adequado diante do instrumento. Para não extrapolarmos a quantidade de força aplicada aconselhamos que a região do pé sobre 0 pedal compreenda apenas um quinto de sua totalidade (a partir da ponta dos pés) e que o seu calcanhar mantenha-se sempre encostado ao chão. A ideia é fazer com que o mecanismo do pedal passe desapercebido no decorrer de uma performance. 


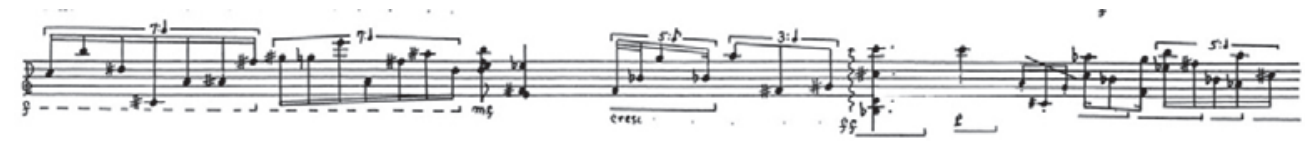

Ex:3: Links 2 (1975; $3^{\circ}$ sistema da pg.2) de Smith: indicação de pedal aberto.

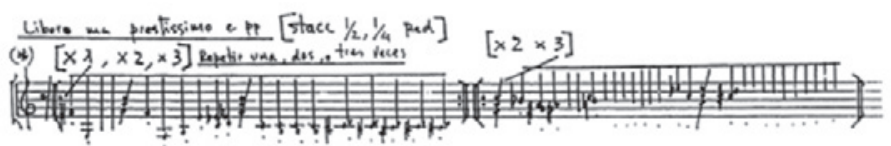

Ex:4: Cálculo Secreto (1994; Início da Seção E) de López López: Indicação de meio-pedal e 1/4 de pedal.

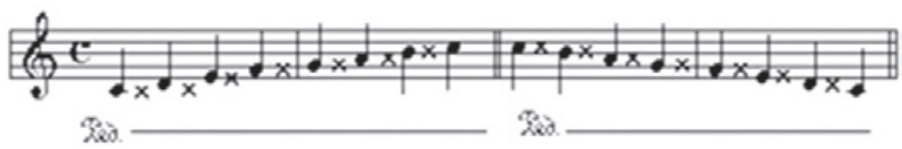

Ex.5: Exercício da escala de Dó Maior ascedente/descendente com marcações de abafamento nota a nota, com exceção do Dó 3 na escala descendente. Na escala ascendente: mão direita toca, mão esquerda abafa.

$\mathrm{Na}$ escala descendente: mão esquerda toca, mão direita abafa.

\subsection{Abafamentos}

Ao perceberem a limitação técnica do pedal relacionado aos abafamentos das lâminas (pois quando acionado, sua interferência dá-se em toda a extensão do instrumento) os vibrafonistas procuraram desenvolver diversas técnicas de abafamento que pudessem auxiliar os fraseados, encadeamentos harmônicos, duração de ressonância das notas, ampliando as possibilidades interpretativas que o instrumento pode oferecer para o instrumentista expressarse musicalmente. As várias técnicas de abafamento que foram desenvolvidas até o momento permitem a exploração de ressonâncias e a ausência de som, em simultâneo, em lâminas distintas. 0 artefato principal utilizado para a realização desses abafamentos é a própria baqueta utilizada para tocar o instrumento. Em alguns casos, o uso da mão ou dos dedos também será uma possibilidade relevante. É como se as próprias mãos do intérprete (auxiliado pelas baquetas) se tornassem uma espécie de segundo pedal, abafando apenas as notas desejadas. Em geral, identificamos o sinal de abafamento em uma obra (sem a utilização do pedal) por um "x" sinalizado logo após a nota que se deseja abafar: "Um ' $x$ ' marcado imediatamente após a nota significa que essa deve ser abafada sem a utilização do mecanismo de pedal, mas pressionando a lâmina com o auxílio do dedo ou de uma baqueta" BURTON (1966, p.1).

Sejourné e Friedman também utilizam o mesmo tipo de sinal para indicar esse tipo de abafamento. Acrescentam, no entanto, um tipo de abafamento que ambos denominam como dead stroke. Essa indicação será pelo sinal "+", que se localiza por cima da nota que deve ser abafada. Na literatura em língua portuguesa especializada não existem nomenclaturas ou termos técnicos para os tipos de técnicas de abafamento aplicados no vibrafone. Indicaremos por tanto os termos em inglês (por se tratarem de expressões existentes na literatura internacional) com a sua tradução (ou adaptação) para o portuguêes ${ }^{15}$ :

1 - Toque preso (dead stroke): Ataque sem rebote da baqueta sobre a lâmina. Ao realizarmos um ataque contra a lâmina a baqueta permanecerá sobre a mesma, inviabilizando a sua vibração, como afirma Friedman: " [...] Notas mortas. Permanecer a baqueta sobre a lâmina, cessando a sua ressonância" FRIEDMAN $(1987$, p.6). Será um som extremamente seco e curto.

2 - Abafamento em deslize (slide dampening): Poderá ser realizado com as duas mãos ou com uma apenas. A baqueta deslizará de uma lâmina para outra (geralmente em grau conjunto ou em movimento cromático), abafando-a. Poderá ser realizado atacando as notas com uma mão e deslizando a baqueta sobre as lâminas com a outra, efetuando o abafamento. Pode-se aproveitar o movimento de articulação em uma nota e deslizar a baqueta em direção à lâmina que ressoava anteriormente (nesse caso o abafamento poderá ser realizado em simultâneo com as duas mãos).

3 - Mãos combinadas (opposite hand combinations): Consiste na realização da articulação nas lâminas com uma das mãos e 0 abafamento das mesmas lâminas com a outra mão, logo após o ataque. Diferentemente do abafamento em deslize executado com a mesma mão (onde a nota é abafada subsequentemente ao ataque realizado em outra nota), as notas devem ser abafadas em simultâneo às lâminas subsequentes atacadas. Um exemplo simples seria tocarmos a escala de Dó Maior ascendente com a mão direita e abafarmos as lâminas com a mão esquerda, realizando o movimento inverso de ataque e abafamento das mãos na escala descendente (Ex:5 acima) 
4 - Combinação com a mesma baqueta (same mallet combinations): Será o abafamento das lâminas efetuado pela mesma mão que realiza o ataque. Para percebermos esse tipo de abafamento visualizaremos a mão esquerda abafando as notas que executa na região grave do instrumento e mão direita realizando o mesmo gesto (alternadamente com a mão esquerda) na região aguda.

5 - Abafamento com as mãos (hand dampening): 0 vibrafonista fará uso da própria mão para abafar as lâminas. Podem ser usados os dedos, o punho, o cutelo16. Não há uma forma exata de se aplicar essa técnica. Cada intérprete utilizará da forma que melhor lhe convier a posição da mão para a realização desse tipo de abafamento.

6 - Abafamento de intervalos (double stops): Aqui o vibrafonista deve ter obrigatoriamente duas baquetas em cada mão. Um intervalo deve ser abafado pela mesma mão que realizou o seu ataque, ao mesmo tempo em que a outra mão executará um ataque em outro intervalo. Frisemos que o intervalo deve ser atacado ao mesmo tempo (um uníssono), alternadamente entre a mão direita e a mão esquerda.

7 - Baqueta com baqueta (mallet to mallet) Esse tipo de abafamento é, tecnicamente, bastante peculiar e difícil, pois consiste em atacar uma lâmina e abafar outra utilizando as duas baquetas de uma mesma mão. Ou seja, se pensarmos por exemplo na mão direita, atacaremos uma nota com a baqueta 3 (ou 4) abafando, em simultâneo, outra nota com a baqueta 4 (ou 3).

8 - Abafamento com o corpo (body dampening) Realiza-se, geralmente, com a parte abdominal do corpo (podendo expandir-se para outras regiões). Para exemplificarmos esse tipo de técnica de abafamento consideraremos a seguinte situação: podemos nos deparar com passagens onde a mão esquerda esteja sobre a região grave do instrumento e a mão direita sobre a última oitava. Considerando que ambas as mãos estarão realizando figuras numa determinada velocidade que as tornam incapazes de se deslocarem para as regiões opostas no intuito de realizarem abafamentos, o corpo poderá executar esse papel encostando-se nas lâminas interrompendo a sua vibração.

É importante destacar que um dos grandes desafios na realização desses abafamentos é o de tornar inaudivel 0 toque do artefato (baqueta, mão, corpo) que realiza esse efeito. Será necessário calcular a força exata do toque para que consigamos abafar completamente uma lâmina sem tornar perceptível o ataque sobre ela. Os abafamentos têm como objetivo cessar as ressonâncias de notas estranhas à harmonia ou a um trecho executado que procure valorizar certas consonâncias ou dissonâncias. Isso acarretará um outro desafio não menos importante que se trata, justamente, do sincronismo que deverá existir entre 0 abafamento e 0 ataque das notas tornando simultâneo o desaparecimento de uma e o aparecimento de outra (ou outras, no caso de intervalos ou acordes).
Esses são alguns exemplos de técnicas de abafamentos mais utilizados e indicados na literatura especializada. Contudo, o intérprete poderá escolher a forma que melhor Ihe convier para realizá-los (inclusive desenvolvendo a sua maneira particular, se for o caso), tornando a passagem executada mais coerente com o que ser quer demonstrar musicalmente. Não existe a necessidade de executarmos essas técnicas independentes umas das outras. Todas elas são perfeitamente adaptáveis e poderão ser combinadas entre si, permitindo o máximo de comodidade ao instrumentista para a execução musical.

\subsection{Manipulação de Arcos}

Um grande número de obras escritas para vibrafone exige do intérprete a manipulação de arcos de instrumentos de corda sobre o instrumento. A espessura da crina dos arcos utilizados é de fundamental importância para a obtenção de um som com maior qualidade, permitindo maior vibração das lâminas, proporcionando uma grande exploração de harmônicos, influenciando o som e a dinâmica. Para facilitar a sua manipulação sobre o vibrafone sugerimos os chamados "Arcos Júnior"17, que conservam a espessura da crina mas são de menor peso e comprimento, facilitando o seu manejo em passagens tecnicamente difíceis. Os arcos de crina preta possuem maior aderência e podem ajudar na relação de atrito com as lâminas. Existem também baquetas de lâminas confeccionadas artesanalmente para esse tipo de repertório, possuindo um sistema de crina já esticada acoplado ao cabo, permitindo a utilização em simultâneo do artefato.

Quanto maior for a pressão sobre a parte perpendicular da lâmina, maiores serão os níveis de vibração da mesma. A partir do momento em que o arco fecha 0 ângulo em direção à superfície do vibrafone, o som poderá ser prolongado, mas dificilmente haverá uma alteração sonora de grandes proporções, pois o contato da crina contra a lâmina diminui. Vejamos os níveis de pressão do arco que devem ser exercidos sobre a lâmina para a obtenção do som desejado:

a) Som contínuo sem alteração - Após o surgimento do som, a pressão do arco contra a lâmina deve ser aliviada procurando o equilíbrio entre os dois, permitindo um som contínuo sem alteração de dinâmica. 0 ângulo do arco fechado sobre a superfície do instrumento poderá ajudar a equilibrar o som;

b) Dinâmica Crescente - A pressão do arco contra a lâmina deverá aumentar conforme os níveis de dinâmicas crescentes indicados. Preferencialmente 0 ângulo do arco deverá permanecer em $90^{\circ}$ em relação à superfície do instrumento;

c) Dinâmica Decrescente - A pressão do arco contra a lâmina deverá diminuir conforme os níveis de dinâmicas decrescentes indicados. A mudança de ângulo do arco contra a lâmina poderá ajudar nessa questão.

Para extrairmos um som extremamente ressonante a crina deve estar em contato com a parte da lâmina que é perpendicular ao chão, perfazendo um ângulo de $90^{\circ} \mathrm{com}$ 
a superfície do vibrafone extraindo-se maiores níveis de vibração da lâmina. Dessa forma será mais fácil controlar as dinâmicas e o som desejado (Ex.6). Para obtermos sonoridades do vibrafone utilizando o arco devemos exercer uma leve pressão da crina contra a lâmina, deslizando-o num sentido vectorial de cima para baixo ou de baixo para cima criando um atrito inicial para que a lâmina comece a vibrar. 0 fato de iniciarmos o toque contra a lâmina com a parte mais espessa da crina (de baixo para cima) ajuda-nos a ter um maior controle sobre a obtenção inicial do som. 0 arco deverá realizar um movimento contínuo podendo, eventualmente, deslocar ligeira e gradualmente o ângulo em direção à superfície do instrumento (Ex.7).

0 vibrafonista deve se valer da mesma resina utilizada por violoncelistas e contrabaixistas, ajudando na obtenção de atrito suficiente entre o arco e a lâmina para a extração do som. No início do primeiro movimento do Concerto pour Vibraphone et Orchestre à Cordes de Sejourné, observamos que o executante começará a obra manipulando arcos de instrumento de cordas sobre o vibrafone (Ex.8).
0 segundo e terceiro compasso do Ex.8 apresentam ligaduras e suspensões, sugerindo fraseados longos e reverberantes, sem abafamentos. Interpretamos esse trecho executando todo o valor rítmico da nota com o arco, aumentando gradualmente a sua pressão contra a lâmina, desencostando-o da mesma logo a seguir, deixando o som reverberar realizando um decrescendo natural sem a interrupção do intérprete. Para o último intervalo desse sistema (Dó 4 - Mi 4) deveremos atacar essas notas com bastante pressão sobre a parte perpendicular das lâminas, dessa forma conseguiremos executar a dinâmica indicada. É um trecho de caráter bastante espacial, onde as reverberações das notas se misturam umas às outras. No segundo sistema desse excerto a escrita é mais específica, sendo necessária uma maior clarificação da frase. Sugerimos a ausência total do pedal como recurso abafador e recorremos ao uso do próprio arco para abafar as notas que executa, parando o seu movimento ao realizar uma leve pressão contra as lâminas de maneira lenta e sutil até a execução da próxima nota, sem comprometer a fluência

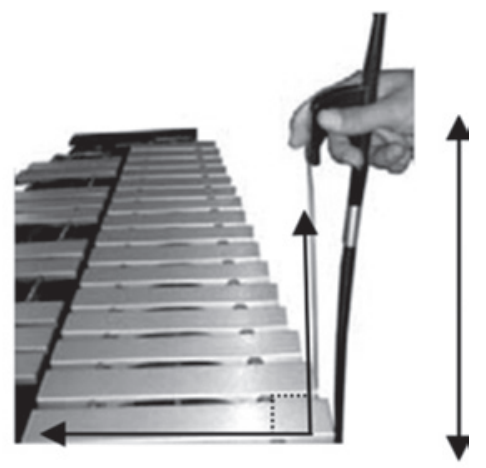

Ex.6: Ângulo de $90^{\circ}$ e movimento perpendicular à superfície do instrumento.

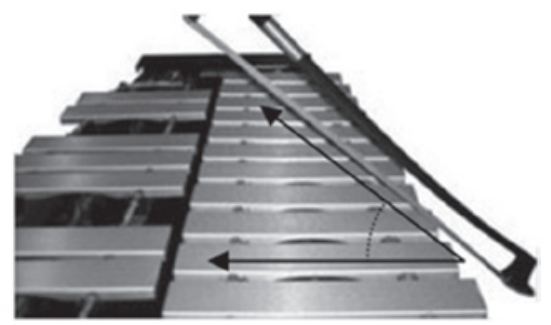

Ex.7: Ângulo do arco deslocado relativo à superfície do instrumento.

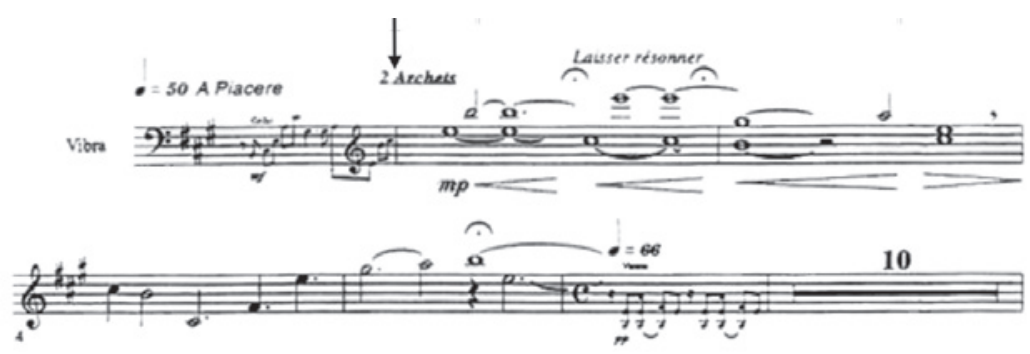

Ex.8: Concerto pour Vibraphone et Orchestre à Cordes (1999; $1^{\circ}$ mov. c. 1-16) de Sejourné: indicação de utilização de arcos. 
da frase. Para uma fluência maior de fraseado e de gesto corporal sugerimos que o sentido seja de baixo para cima, ajudando no movimento do corpo para a execução, por exemplo, das notas - acidente. Apenas em casos extremos (onde o sentido sugerido compromete a execução ou se a nota executada for demasiado longa) o movimento deve alterar-se (de cima para baixo ou alternando os sentidos sucessivamente).

\subsection{Som contínuo}

Muitos instrumentos de percussão têm uma característica original semelhante: a ausência de um som contínuo de longa duração causado pelo ataque da baqueta. Com o vibrafone não é diferente. Percebemos há pouco que quando extraímos o som por fricção conseguimos tornálo mais duradouro. Contudo, não é raro encontrarmos passagens em obras para vibrafone onde o compositor sinaliza a intenção de criar um som contínuo com a utilização de baquetas. Geralmente a visualização gráfica se dá por tr (trinado) ou por um trêmulo de semibreve, mínima, semínima, etc. 0 intérprete em muitos casos, ao iniciar uma música com baquetas duras, sente dificuldade em obter esse efeito sonoro do instrumento pela impossibilidade física da troca de baquetas, procurando não prejudicar a fluência da obra em questão. É preciso ter em conta se a obra lhe dá essa oportunidade de troca, ou optar por baquetas que mais se adaptem às suas características gerais. 0 Concerto pour Vibraphone et Orchestre à Cordes de Sejourné permite a troca de baquetas em todos os trechos que possuem essa característica de um som contínuo. Nesse caso o compositor pede para a mão esquerda realizar um pedal ${ }^{18}$ que será sustentado enquanto a mão direita executa a melodia (Ex.9).

Cabe ao intérprete tornar essa intenção exequível. Para isso faz-se necessária a experimentação de diferentes tipos de baquetas até obtermos o som desejável. Tão relevante quanto à escolha das baquetas será a intenção do toque (ataque ou articulação). Sabemos que as possibilidades de variações sonoras extraídas das lâminas estão diretamente ligadas à relação de dureza das baquetas. Se concluirmos que um som uniforme, longo e contínuo tem em sua nota fundamental a personagem principal do timbre, optaremos por uma baqueta extremamente macia (com cabeça e revestimento de pouca dureza) para a mão esquerda (baquetas 1 e 2) e uma baqueta de dureza maior para mão direita (baquetas 3 e 4) com a intenção de sobrepor a melodia ao acompanhamento. $A$ intenção de toque sobre a lâmina com a mão esquerda deverá ser lenta e contínua. A ideia é não ouvirmos os ataques das baquetas. Partindo do princípio que cada novo toque abafa o anterior, perceberemos que quanto menos toques aplicarmos sobre o instrumento, menor será o risco de ouvirmos os ataques das baquetas. Se a intenção é não ouvirmos esses ataques deveremos ter a preocupação de executar o trecho utilizando o máximo possível a extremidade das cabeças das baquetas, valorizando a ausência de articulação e o timbre extraído pelo material que a reveste. Vejamos a ilustração do posicionamento angular da baqueta sobre a superfície do instrumento, para uma melhor compreensão:

a) Ângulo aberto - maior contato da ponta da baqueta com a lâmina, proporcionando um timbre mais característico da linha que reveste a "cabeça" da baqueta; menores níveis de dinâmica; maior evidência da fundamental nas notas graves; pouca resposta sonora na região aguda do instrumento; ataque com pouca articulação (Ex.10).

b) Ângulo fechado - maior contato da região central da baqueta com a lâmina, proporcionando um timbre mais característico do material com o qual é feita a "cabeça" da baqueta; maiores níveis de dinâmica; fundamental com maior incidência de harmônicos agudos nas notas graves; boa resposta sonora na região aguda do instrumento; ataque com bastante articulação (Ex.11).

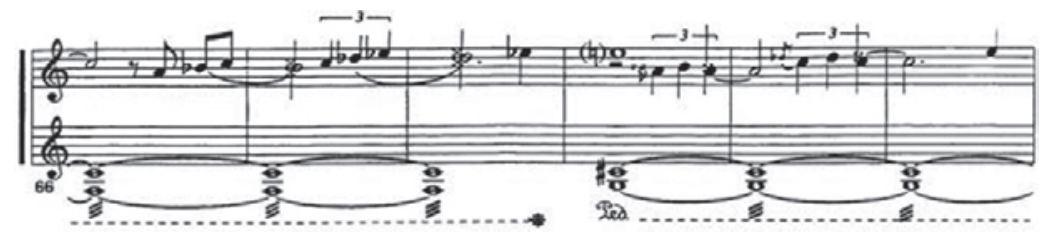

Ex.9: Concerto pour Vibraphone et Orchestre à Cordes (1999; $2^{\circ}$ mov. c. 66-71) de Sejourné: som contínuo na voz de baixo (mão esquerda).

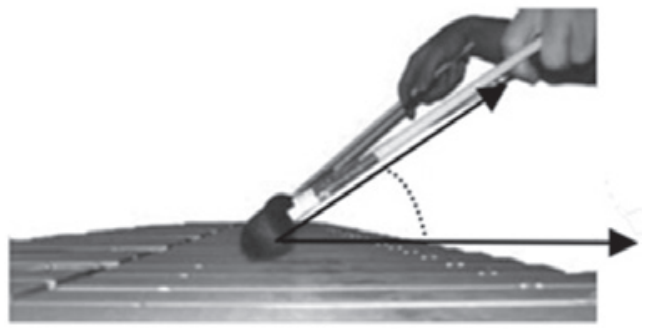

Ex.10: Ângulo aberto.

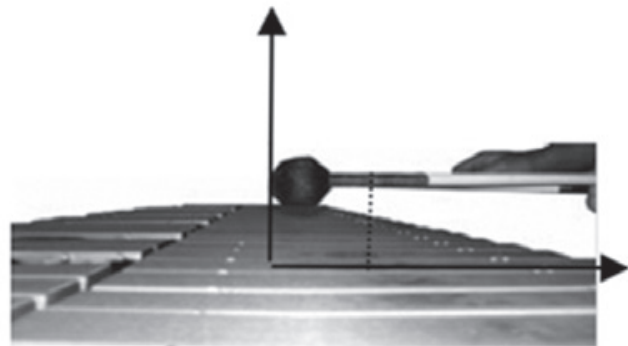

Ex.11: Ângulo fechado. 
Esse artifício não está condicionado apenas às vozes da mão esquerda ou mão direita. Observamos no Ex.12, a indicação de um som contínuo nas vozes intermediárias. As baquetas de menor dureza deverão ser as de número 2 e 3 , enquanto as que possuem maior dureza compreenderão os números 1 e 4 . Esse trecho tem a particularidade de ser executado com o motor funcionando em ritmo lento. Cabe ao intérprete aproveitar esse recurso do instrumento para que a reverberação das notas alcançadas através dos tubos ressonantes ajude na extração do som contínuo.

\subsection{Harmônicos}

Realização de harmônicos com baquetas - podemos extrair harmônicos das lâminas do vibrafone com o simples uso de baquetas de grande dureza (madeira, acrílico, silicone, metal), podendo estar sem o revestimento da cabeça (linha, lã, corda) ou utilizando a extremidade da baqueta (ponta do cabo de ratan ou madeira). 0 som extraído será uma fundamental rica em harmônicos e inarmônicos. A obra Modelagem X-a de Zampronha é um bom exemplo desse tipo de sonoridade. Aqui se especifica que o material do cabo da baqueta deve ser o ratan, e não a madeira (Ex.13).

Devemos iniciar e finalizar esse trecho com a cabeça da baqueta revestida com lã, conforme indicado. Os sons ricos em harmônicos serão explorados no trecho onde está sinalizado o uso do ratan (centro do pentagrama), onde intérprete deverá tocar com o cabo da baqueta. Pela rapidez do gesto e pelas notas que o compõem, sugerimos o uso das pontas do cabo da baqueta (lado inverso à cabeça). Pela impossibilidade de troca de baquetas durante toda a obra, o intérprete vê-se na obrigação de manusear duas baquetas na posição inversa, uma em cada mão, (com o intuito de tocar a parte do ratan na lâmina), do início ao fim da música: "São utilizados dois pares de baquetas: Baqueta de lã dura e ratan. Não há tempo para trocas de baquetas. Deve-se utilizar duas baquetas em cada mão, uma baqueta de lã dura e outra de ratan"19. As posições das baquetas nas mãos podem ser: $1 /$ invertida, 2/normal, 3/invertida e 4 /normal (Ex.14) ou 1/normal, 2 / invertida, 3/normal e 4/invertida (Ex.15).

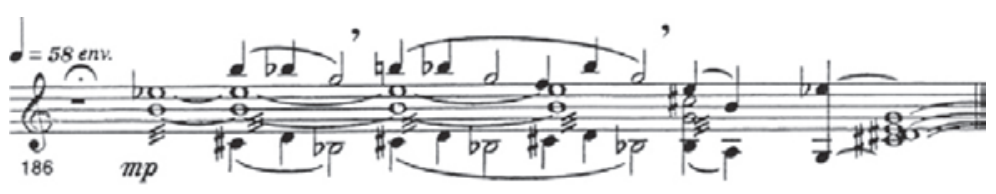

Ex.12: Concerto pour Vibraphone et Orchestre à Cordes (1999; $2^{\circ}$ mov. c. 186) de Sejourné: Vozes intermediárias realizando um som contínuo (baquetas 2 e 3 ).

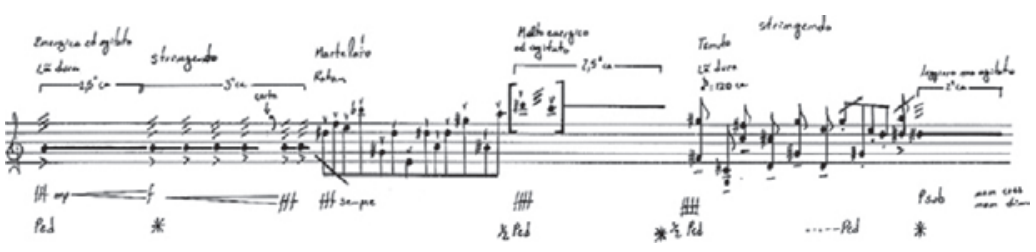

Ex.13: Modelagem X-a (1997; $1^{\circ}$ sistema da pg.2) de Zampronha: indicação do uso de ratan.

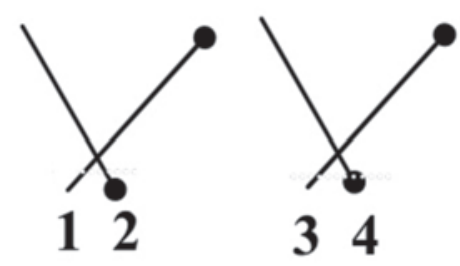

Ex.14: Baquetas 1 e 3 na posição normal e baquetas 2 e 4 na posição invertida.

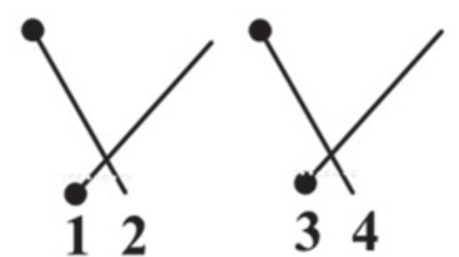

Ex.15: Baquetas 1 e 3 na posição invertida e baquetas 2 e 4 na posição normal. 
É relevante observar que, sendo a articulação influenciada diretamente pelo peso das baquetas (inclusive de suas pontas), os toques realizados com o cabo de ratan terão seus niveis de dinâmica em menor escala do que os realizados com a cabeça da baqueta, certificando que a indicação de fff(Ex.13), escrita no momento da execução com a cabeça revestida, soará mais forte em relação ao ffff, indicado para o ratan. A região de ataque das baquetas sobre as lâminas é determinante para a qualidade dos harmônicos. Quanto mais próximo o ataque do nó, mais audivel será o harmônico 4 (duas oitavas acima da nota fundamental). É interessante perceber que, nesse caso, a fundamental e o harmônico n. 4 praticamente dividem as atenções, sendo as duas notas perfeitamente audíveis.

Para que o harmônico n.4 se sobressaia à nota fundamental, sugerimos um ligeiro apoio de uma baqueta ou de um dos dedos da mão no centro da lâmina enquanto executa-se 0 ataque com outra baqueta (preferencialmente com a cabeça revestida) na região do nó (Exs.16,17 e 18).

Ao ser percutida, o dedo (ou a baqueta) deve ser retirado da lâmina quase que instantaneamente com o intuito de

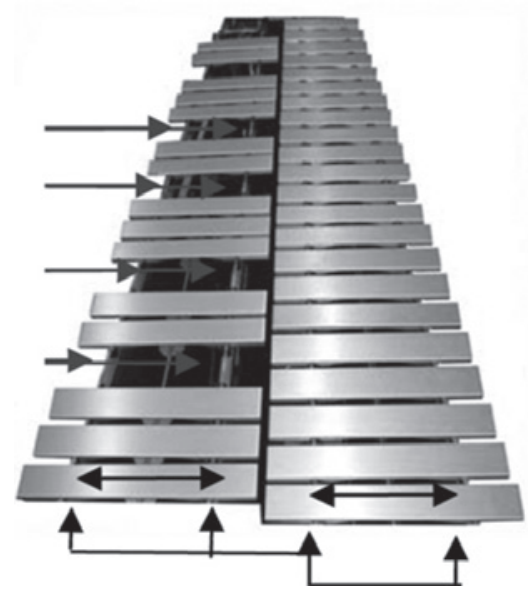

Ex.16: Panorama da superfície de um vibrafone de 3 oitavas. É possivel perceber na escala pentatônica a corda que trespassa as lâminas em seus pontos nodais.

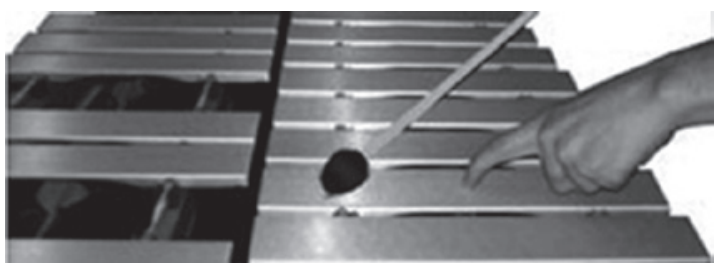

Ex.17: Ataque sobre a região do nó com o dedo apoiado no centro da lâmina. não abafar o som extraído (se a intenção for uma nota de curta duração pode-se manter o apoio no centro). Com esse gesto conseguiremos ouvir nitidamente o harmônico n.4 sem a interferência direta de outras notas.

Outra forma de obter-se harmônicos com baquetas será utilizando o seu cabo ${ }^{21}$ como um elemento de apoio sobre a lâmina. Podemos percutir a lâmina com qualquer tipo de baqueta, tendo o seu cabo levemente apoiado (ou apoiando-o logo após o ataque) em uma das extremidades da lâmina, obtendo um timbre rico em harmônicos e inarmônicos gerando, dentre todos os exemplos aqui citados, o som que mais se aproximará do que chamamos de ruído (Ex.19).

2) Extração de harmônicos com arcos - o harmônico será o n.4 da série harmônica. Sugerimos a utilização dos mesmos arcos mencionados há pouco. A técnica será uma mistura da execução de uma nota fundamental com a técnica de extração de harmônicos com baquetas. Os arcos devem estar na posição que se encontram para a obtenção de uma nota fundamental. Devemos apoiar levemente um dedo no centro da lâmina, manipulando o arco com bastante pressão contra a mesma (Ex.20).

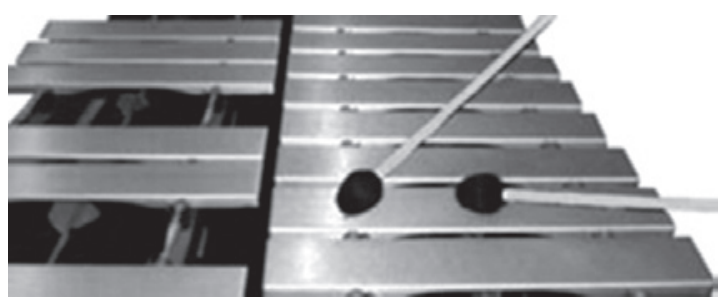

Ex.18: Ataque sobre a região do nó com a baqueta apoiada no centro da lâmina.

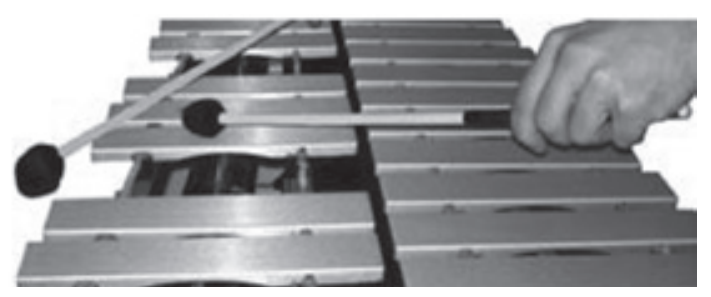

Ex.19: Apoio do cabo e ataque sobre a lâmina.

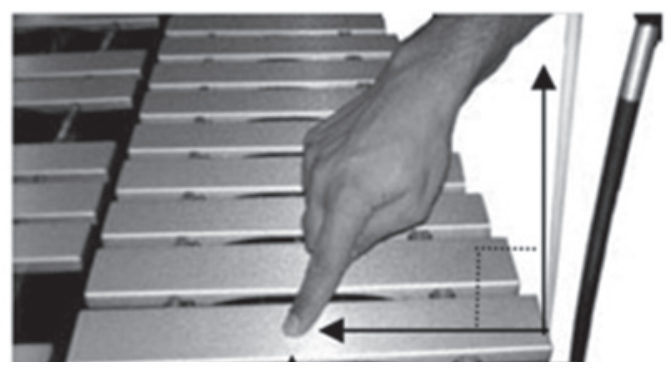

Ex.20: Deslize do arco e dedo no centro da lâmina. 
Dessa vez, devido à grande pressão exercida para o surgimento do harmônico, sugerimos o sentido vetorial dos arcos de cima para baixo com o intuito de não fazer "saltar" a lâmina do local onde ela se encontra suspensa ${ }^{22}$. 0 sentido deve ser contrário apenas se o primeiro comprometer a execução e fluência da obra. 0 dedo pode manter-se sobre a lâmina, mas o harmônico terá maior projeção sonora se o retirarmos enquanto o arco é deslizado. O segundo movimento do Concerto pour Vibraphone et Orchestre à Cordes de Sejourné possui uma passagem onde essa questão é bem exemplificada (Ex.21).

3) Extração de harmônicos com outros instrumentos - A utilização de pratos de dedo ${ }^{23}$, por exemplo, gera uma mistura de harmônicos das lâminas com os do próprio instrumento utilizado como artefato para percutir o vibrafone. Será uma mescla de harmônicos e inarmônicos com a presença da nota fundamental da lâmina percutida. É possível ainda realizar esse tipo de ação no vibrafone com instrumentos não convencionais. Podemos utilizar correntes de ferro, pincéis, espátulas, dentre muitos outros artefatos, que fazem parte da uma lista interminável, capazes de produzir diferentes tipos de colorido sonoro nesse instrumento. Até mesmo as mãos podem ser utilizadas como um instrumento de ataque sobre as lâminas. As unhas dos dedos podem extrair perfeitamente das lâminas fundamentais ricas em harmônicos, mas com menores níveis de dinâmica.

\subsection{Glissando}

0 efeito de glissando nos instrumentos de percussão de lâminas é realizado através do deslize das baquetas sobre a sua superfície, num movimento horizontal para direita ou para a esquerda (ou para ambos os lados). No entanto o vibrafone possui uma particularidade interessante: as suas lâminas permitem a realização, em si próprias, de glissandi micro tonais até meio-tom, podendo ser descendentes, ascendentes ou um som contínuo descendente/ascendente. Vejamos os tipos de glissandi possíveis de se extrair do vibrafone, tendo em vista as alternativas de deslize da baqueta sobre a lâmina:

a) Glissando descendente - ataque no centro da lâmina. Deslize da baqueta dura apoiada sobre o nó da lâmina em direção ao centro da mesma;

b) Glissando ascendente - ataque em uma das extremidades da lâmina. Deslize da baqueta dura apoiada no centro da lâmina em direção a um dos nós da mesma. É importante salientar que o glissando ascendente terá menor incidência sonora do que os outros tipos. Isso acontece porque o apoio da baqueta no centro da lâmina interfere em sua vibração, abafando consideravelmente 0 som extraído;

c) Glissando descendente/ascendente - ataque no centro da lâmina. Deslize da baqueta dura apoiada sobre um dos nós da lâmina em direção ao outro nó, passando a baqueta por toda a extensão da lâmina que se encontra entre os dois nós.

1) Realização de glissando com baquetas - deveremos utilizar uma baqueta extremamente dura sem revestimento (silicone, acrílico, borracha dura) e uma baqueta de menor dureza (preferencialmente com revestimento). Percutiremos no centro da lâmina com a baqueta revestida, tendo a baqueta dura apoiada no nó da mesma. No momento do ataque com a baqueta revestida deslizaremos a baqueta dura sobre a lâmina em um movimento contínuo até o centro, exercendo certa pressão que não poderá ser em demasia correndo o risco do som da lâmina ser abafado (Ex.22).

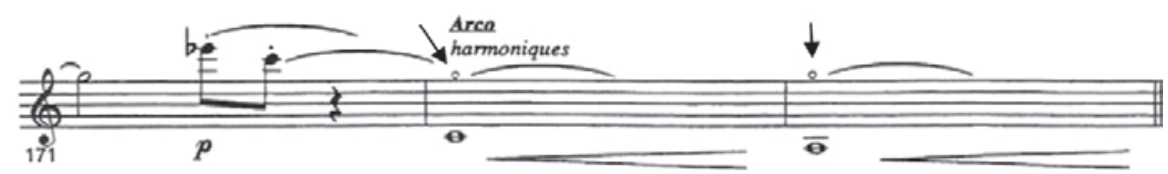

Ex.21: Concerto pour Vibraphone et Orchestre à Cordes (1999; $2^{\circ}$ mov. c. 171-173) de Sejourné: Indicação de harmônicos.

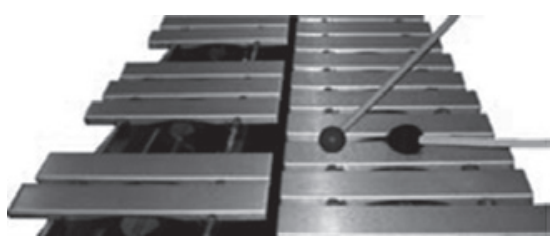

Ex.22: Ataque no centro da lâmina (baqueta revestida) e deslize da baqueta dura a partir da região do nó em direção ao centro da lâmina. 
Para o glissando ascendente o posicionamento das baquetas é invertido. A baqueta dura estará apoiada no centro da lâmina e a baqueta revestida percutirá no limite de uma das extremidades da lâmina. É importante salientar que o ataque deve se concentrar no limite extremo da lâmina, distante do nó, caso contrário a fundamental não será perfeitamente audivel para a realização desse efeito (Ex.23).

Dessa vez a baqueta dura deslizará, também em movimento contínuo, em direção ao nó da lâmina. 0 fato dos dois atos serem percutidos em diferentes regiões da lâmina influencia diretamente na dinâmica da nota extraída. Obviamente o glissando descendente por ser extraído a partir de um ataque no centro da lâmina será mais audivel do que o ascendente originado de um ataque feito a partir de uma de suas extremidades. Para extrair o efeito descendente/ascendente basta deslizar a baqueta dura num movimento contínuo, com sua devida pressão sobre a lâmina de um ponto nodal ao outro. Existe a indicação, em determinado trecho do Concerto pour Vibraphone et Orchestre à Cordes de Sejourné, do efeito de glissando de uma nota à outra, sem a indicação nítida de sentido. Graficamente poderíamos concluir que todos os glissandi apontados nesse trecho possuem um sentido descendente, já que o símbolo utilizado perfaz um desenho vetorial de cima para baixo (Ex.24).

2) Realização de glissando com arcos - nesse caso a manipulação da baqueta dura será exatamente a mesma e sua relação deslize também. Utilizaremos o arco no lugar da baqueta revestida. 0 arco deverá deslizar sobre a lâmina exatamente como faz para a execução de uma dada nota. Deverá apenas exercer maior pressão contra a lâmina, já que essa possui uma baqueta apoiada sobre si dificultando a sua projeção sonora. 0 movimento do arco e da baqueta dura (o deslize de ambos) deve ser sincronizado. Enquanto a baqueta desliza em direção ao centro (ou ao nó), o arco deve deslizar para cima ou para baixo (Ex.25).

0 efeito extraído com o arco assemelha-se ao executado com baquetas revestida por apresentar as mesmas características descendente, ascendente ou descendente/ ascendente. Irá, no entanto, se diferenciar pelos níveis de dinâmica, pela sua duração (controlando o som através do deslize do arco) e sonoridade diferente. 0 glissando com arco, indicado no Concerto pour Vibraphone et Orchestre a Cordes, deve soar descendente/ascendente conforme 0 desenho gráfico que corta as notas Mi e Sol (Ex.26).

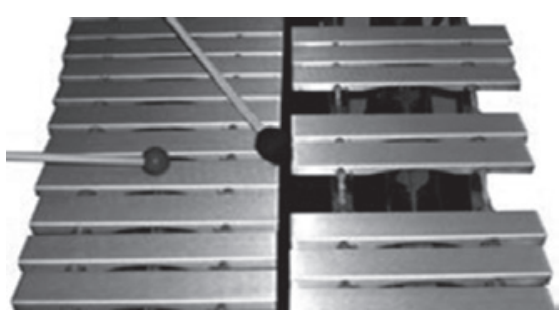

Ex.23 Deslize da baqueta dura do centro da lâmina em direção ao nó e ataque na extremidade da lâmina (baqueta revestida).

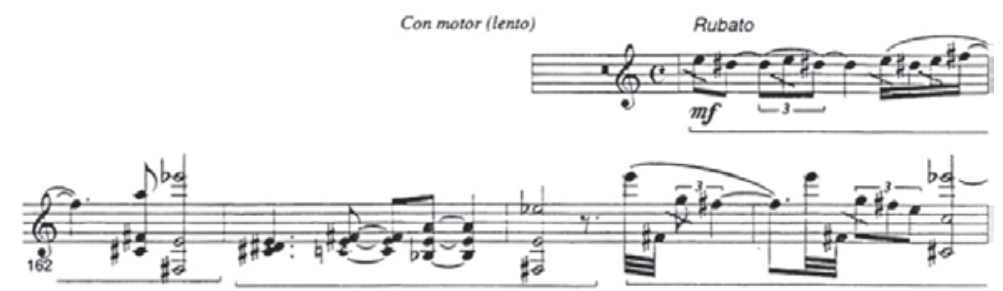

Ex.24: Concerto pour Vibraphone et Orchestre à Cordes (1999; $2^{\circ}$ mov. c.161-165) de Sejourné: Indicação de glissando.

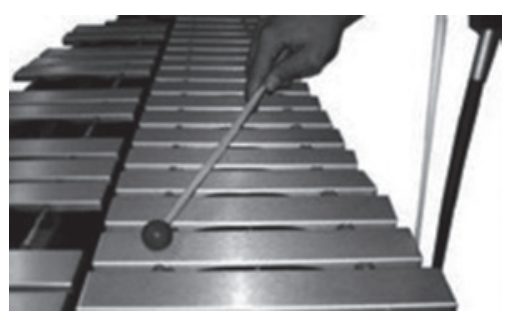

Ex.25: Deslize da baqueta dura, apoiada no ponto nodal, em direção ao centro da lâmina (ou ao nó que se situa na outra extremidade da lâmina) e deslize do arco sobre a lâmina num sentido perpendicular ao instrumento. 


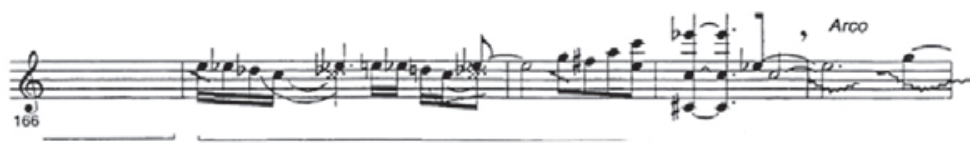

Ex.26: Concerto pour Vibraphone et Orchestre à Cordes (1999; 2 mov. c. 166-170), de Sejourné: Indicação de glissando com arco.

\section{4 - Considerações finais}

Procuramos, através desse artigo, exemplificar meios de exploração tímbrica no vibrafone com o intuito de criar ferramentas que auxiliem no processo de interpretação e composição de obras destinadas ao vibrafone. Os compositores, durante todo o século $\mathrm{XX}$, em conjunto com os intérpretes, souberam explorar muito bem essas características técnicas e sonoras que o instrumento nos permite usufruir, enriquecendo o repertório destinado ao vibrafone com composições bastante singulares.
Percebemos diante de todos esses exemplos uma real versatilidade desse instrumento no que diz respeito à capacidade de recursos que ele nos oferece para a exploração de um vasto universo tímbrico. Outrossim, admitimos a existência de outras formas de exploração tímbrica aqui não mencionadas, o que certamente estimulará a produção de novos artigos e trabalhos que possam contribuir e enriquecer o leque de possibilidades de performance musical referentes ao vibrafone.

\section{Referências}

ALMEIDA, F. Entrevista concedida em 12/04/2007. Aveiro, Portugal.

BURTON, G. Introduction to Jazz Vibes. Nova lorque: Creative Music, 1966.

CHAIB, F. Exploração Tímbrica no Vibrafone: Análise Interpretativa da obra Cálculo Secreto, de José Manuel López López. Universidade de Aveiro, Aveiro, 2007.

DEANE, C. Mourning Dove Sonnet. Manuscrito do autor, 1983.

FRIEDMAN, D. Vibraphone Technique: Dampening and Pedalling. Berklee Press Publications, 1973. Mirror From Another - A Collection of Solo Pieces for Vibraphone. Belwin Mills, Fl. 1987.

FRUNGILLO, M. D. Dicionário de Percussão. São Paulo: Editora Unesp, 2002.

LÓPEZ LÒPEZ, J. M. Cálculo Secreto. Partitura manuscrita. Madrid, 1994.

SCHAEFFER, P. Traité dês Objects Musicaux. Paris: Nouvelle Edition, 1966.

SEJOURNÉE, E. Concerto Pour Vibraphone et Orchestre à Cordes. Paris: Alphonse Leduc, 1999.

SMITH, S. S. Links, Links no.2, Links no.3. Nova lorque: Smith Publications, 1975.

TAKEMITSU, T. Rain Tree. Tienen, Bélgica: Percussion Music Europe, 1981.

UDOW, M, WATTS, C. The Contemporary Percussionist: 20 Multiple Percussion Recital Solos.

Meredith Music Publications. Ft. Lauderdale, 1986.

ZAMPRONHA, E. Entrevista concedida em 20/03/2007. Aveiro, Portugal. Modelagem X-a. Partitura manuscrita, São Paulo, 1997.

\section{Literatura Recomendada}

CHAIB, F. Let Vibrate: Um breve panorama sobre o vibrafone na música do século XX. OPUS, Goiânia, v.14 n.1 p.50-64, 2008.

DELP, R. Vibraphone Technique: four-mallet chord voicing. Berklee Press Publications, 1975.

HOLLY, R. Feature: Vibraphone - Introduction. Percussive Notes, v. 25, n. 2, p. 7-16, 1987.

HOWLAND, H. The Vibraphone: A Summary of Historical Observation with a Catalogue of Selected Solos and Small Ensemble Literature. Percussive Notes Research Edition, v. 14, n. 3, p. 77-93, 1977.

LESNIK, I. Milhaud's Concerto for Marimba, Vibraphone and Orchestra. Percussive Notes. v. 35, n. 3, p. 58-60, 1997.

MOLENHOF, B.; SAINDON, E.; WIENER, R. Vibraphone Feature Intro. Percussive Notes. v. 22, n. 1, p. 46-62, 1983.

SAMUELS, D. A Musical Approach to Four-Mallet Technique for the Vibraphone vol. 1 \&t 2. New

York: Manhattan Music Publications. (s/d).

WELSH, J. P. Stuart Smith's "Links" Series. Percussive Notes Research Edition. v. 21, n. 3, p.75-89. 1983. 


\section{Notas}

1 Todas as traduções são de responsabilidade do autor desse artigo.

2 Chamaremos de "som original" o som extraído do ataque das baquetas (com cabeça de borracha revestida com lã ou linha) sobre as lâminas, visto que originalmente o vibrafone foi concebido para ser executado dessa maneira.

3 Terminologia em língua portuguesa utilizada no Brasil.

4 Terminologia em lingua portuguesa utilizada em Portugal.

5 "Termo em inglês para baqueta de instrumento de teclado (lâminas)." FRUNGILLO (2002, p.200).

"Termo brasileiro - Tipo de bambu maleável e resistente utilizado para servir de cabo de baquetas". FRUNGILLO (2002, p. 271).

Na literatura internacional especializada encontramos a denominação em inglês: Double Sound ou Double Tone.

"Termo brasileiro, s.f., pl. = 'manulações' - Forma de indicar a "mão" a ser usada na execução." FRUNGILLO (2002, p.201).

9 No texto original a indicação se dá por $L$ ("Left") para esquerda e $R$ ("Right"). Em língua portuguesa será: $L=E$ e $R=D$.

10 "Metalofone [...] o termo fixou-se para indicar o instrumento feito com barras retangulares de metal dispostas na forma de um teclado diatônico, similar ao Glockenspiel e ao vibrafone. Difere desses ou por ser feito de outro tipo de metal ou por ser utilizado o teclado sem abafador e sem motor". FRUNGILLO (2002, p.221).

11 Segundo a fábrica brasileira Jog Music.

12 UDOW, WATTS (1986).

13 Medida em segundos do ataque da nota até o momento em que ela torna-se inaudivel.

14 Cálculo Secreto (1994). Parte manuscrita pelo compositor. Segundo a dissertação de mestrado "Exploração Tímbrica no Vibrafone: Análise Interpretativa da obra Cálculo Secreto, de José Manuel López López", de Fernando Chaib, esse trecho faz parte da Seção E da obra.

15 Aproximaremos a tradução em língua portuguesa para uma percepção linguística relacionada à técnica aplicada no instrumento. Por exemplo, "stroke" significa "golpe", mas aqui traduziremos para "toque". Será uma tradução com a intenção de criar expressões técnicas.

16 Parte lateral da mão, abaixo do dedo mindinho.

17 Arcos para crianças, existente no mercado.

18 Trêmulo de semibreves com a mão esquerda.

19 Modelagem X-a: Instruções (1997).

20 Terminologia em língua portuguesa para a região dos pontos nodais das lâminas, por onde trespassa a corda que a sustenta sobre a superfície do instrumento.

21 Aqui, o ratan trará melhores resultados sonoros do que a madeira.

22 Em alguns modelos de vibrafone as cordas que trespassam as lâminas não estão totalmente presas ao instrumento, mas apenas apoiadas por ganchos em forma de "u" dispostos nas barras de sustentação.

23 [Ingl.] Finger Cymbals (FRUNGILLO: 2002, p.125).

Fernando Chaib gradou-se em Bacharelado em Percussão pela UNESP, realizando Mestrado em Música/Performance na Universidade de Aveiro. Vencedor de prêmios como solista e músico de câmara no Brasil, na Itália e em Portugal, é membro fundador do Grupo Durum Percussão Brasil e Simantra Grupo de Percussão. Possui Cd's gravados com orquestras e grupos de música de câmara. Realiza concertos (a solo e diante de orquestras) e master classes nos continentes americano, asiático e europeu. Atualmente, cursa o Doutorado em Música na Universidade de Aveiro sob orientação do Prof. Dr Evgueni Zoudilkine e Prof. Dr.Miquel Bernat, sendo bolsista da Fundação para a Ciência e Tecnologia (FCT) de Portugal e pesquisador do INET-MD. 